УДК $316.3,316.4,32.019 .52,323.2$

$10.17213 / 2075-2067-2021-2-29-40$

\title{
РОССИЙСКАЯ МОЛОДЕЖЬ О ПЕРСПЕКТИВАХ И ОБРАЗАХ БУДУЩЕГО СОЦИАЛЬНО-ПОЛИТИЧЕСКОГО РАЗВИТИЯ СТРАНЫ
}

\author{
(C) 2021 г. Н. М. Великая, И. С. Шушпанова
}

\author{
Институт социально-политических исследований \\ Федерального научно-исследовательского социологического центра РАН, \\ 2. Москва, Россия
}

Целью исследования в статье является анализ социально-политических аспектов сложившихся образов будущего у российской молодежи. Отдельно рассматривается уровень доверия к президентской власти, который является важным индикатором легитимности государственных институтов, и отношение молодежи к поправкам в Конституцию РФ. Учитывая высокий уровень глобализации российского общества, авторы анализируют перспективы внешнеполитического курса и возможности геополитического положения России в ближайшей перспективе с точки зрения молодежи.

Методологическая база исследования основывается на применении системного, комплексного подхода к исследованию перспектив и образов будущего в оценках российской молодежи. Авторы строили свое исследование на изучении широкой теоретической базы, проанализировав труды ведущих ученых, практиков в области сочиологии молодежи, политической сочиологии и других смежных дисииплин. На этой основе было разработано оригинальное методическое обеспечение исследовательского авторского проекта. Эмпирическую базу составили результаты сочиологического исследования «Устойчивость социально-политического развития российского общества и меняюшийся образ будущего в массовом сознании граждан», проведенного Центром стратегических соџиальных и сочиально-политических исследований ИСПИ ФНИСЦ РАН в декабре 2020 года с участием авторов.

Результаты исследования. По мнению молодежи, идеальный образ сочиально-политического развития страны имеет гибридный характер, основывается как на общечеловеческих иенностях, так и на противостоящих друг другу политико-идеологических. Образ будущего развития глазами молодых граждан в разрезе оченки перспектив внутренней и внешней политики предполагает руководство страной сильного, с твердой рукой президента, который способен сдерживать внутренние и внешние конфликты, активно развивая отношения на международной арене. В то же время протестный потенциал молодежи не угрожает устойчивости современной политической системы и во многом сдерживается высоким уровнем уверенности в завтрашнем дне и социальным оптимизмом. В статье также делается вывод об устойчивости политической культуры, которая демонстрирует преемственность и наличие раскола по основанию выбора предпочтительного сочиального строя: капитализма или соииализма.

Перспективу исследования составляет продолжение сбора, анализа новой и имеющейся мониторинговой социологической информации с иелью выявления тенденций, трендов трансформащии образов будущего сочиально-политического развития страны в оценках российской молодежи.

Ключевые слова: молодежь; образ будущеего; устойчивое социально-политическое развитие российского общества; государство; власть; гражданское общество; доверие; 
Конституциия РФ; внутренняя политика; внешняя политика; сочиализм; капитализм; экономика; общественное мнение.

\title{
RUSSIAN YOUTH ABOUT PROSPECTS AND IMAGES OF THE FUTURE SOCIO-POLITICAL DEVELOPMENT OF THE COUNTRY
}

\author{
(C) $2021 \quad$ N. M. Velikaya, I. S. Shushpanova
}

\section{Institute of Socio-political Research of the Federal Research Sociological Center of the Russian Academy of Sciences, Moscow, Russia}

The purpose of the research in the article is to analyze the socio-political aspects of the current image of the future among Russian youth. The level of trust in the presidential power, which is an important indicator of the legitimacy of state institutions, and the attitude of young people to the amendments to the Constitution of the Russian Federation are considered separately. Taking into account the high level of globalization of the Russian society, the authors analyze the prospects of the foreign policy course and the possibilities of the geopolitical position of Russia in the near future from the point of view of the youth.

The methodological framework of the research is based on the application of a systematic, integrated approach to the study of prospects and images of the future in the assessments of Russian youth. The authors based their research on the study of a broad theoretical base, analyzing works of the leading scientists and practitioners in the field of youth and political sociology and other related disciplines. On this basis, the original methodological support of the research project was developed. The empirical base was formed by the results of the sociological study "The stability of the sociopolitical development of Russian society and the changing image of the future in the mass consciousness of citizens», conducted by the Center for Strategic Social and Socio-Political Studies of the ISPI of the Russian Academy of Sciences in December 2020 with the participation of the authors.

The results of the study. The ideal image of the socio-political system has a hybrid character, based both on universal values and on opposing political and ideological ones. The protest potential of young people does not threaten the stability of the modern political system and is largely constrained by a high level of confidence in the future and social optimism. The conclusion about the stability of political culture, which demonstrates continuity and the presence of a split on the basis of choosing the preferred social system: capitalism or socialism, is also drawn in the article.

The perspective of the research is the continuation of the collection and analysis of new and existing monitoring sociological information in order to identify tendency in the transformation of images of the future socio-political development of the country in the assessments of Russian youth.

Key words: youth; image of the future; sustainable socio-political development of Russian society; state; government; civil society; trust; Constitution of the Russian Federation; domestic policy; foreign policy; socialism; capitalism; economy; public opinion.

Введение. Мировоззрение молодежи традиционно является одним из самых актуальных предметов социологических исследований, что определяется пониманием того факта, что именно молодежь является социальной базой и субъектом настоящих и будущих обще- ственных перемен. При этом доминирующие смысложизненные ценности этой социальной группы, озабоченность судьбами страны, ответственность перед ближним кругом и перед обществом в целом, интерес к окружающему миру и высокий уровень социального опти- 
мизма, а главное, готовность к определенным социальным действиям и склонность к радикализму - вот основные черты, традиционно приписываемые молодежи [2].

Отдельно стоит обратить внимание на тот факт, что глобализационные процессы, связанные прежде всего с глобализацией информации, оказывают существенное влияние на молодое поколение: политические изменения, экономические преимущества других систем, провалы политики в других странах моментально становятся достоянием общества. В этом смысле молодежь, имеющая доступ к новейшим технологиям, больше включена и в международную повестку дня, что влияет на ее восприятие актуальной политической и экономической ситуации в стране [2]. Нам было важно увидеть также, в какой мере представления о будущем современной российской молодежи совпадают с установками старшего поколения, какой путь развития страны она считает предпочтительным, какой она видит современную политическую систему России.

В контексте изучения теоретико-методологической базы авторы проанализировали труды ведущих исследователей в области социологии молодежи и политической социологии: Ю. А. Зубок, В.И. Чупрова [5-7, 1316], А. И. Ковалевой, В.А. Лукова, Э. К. Погорского, Д. А. Тихомирова $[8,11]$, Н. М. Великой [2], В.К. Левашова, И.С. Шушпановой $[17,10]$ и других. Также авторами был проведен анализ работ широкого круга ученых и практиков, исследовавших образ будущего в контексте изучения социально-политических аспектов развития общества. Среди них можно выделить труды таких авторов, как В. С. Бочко, Е.А. Захарчук [1], А.В. Глухова, О.А. Сиденко, Д. В. Сосунов, Д.В. Щеглова [3], В.А. Зимин [4], В.В. Гаврилюк, Л.Л. Мехришвили, Н.И. Скок, Х.Н. Садыкова, Ш.Ф. Фарахутдинов, В.В. Маленков, Т.В. Гаврилюк, О.Л. Сотков, И.Н. Голиков [12], Ф. Полак [18] и др.
Эмпирическую базу исследования составили результаты всероссийского социологического исследования, проведенного в декабре 2020 года Центром стратегических, социальных и социально-политических исследований ИСПИ ФНИСЦ РАН с участием авторов статьи ${ }^{1}$ и других мониторинговых исследований [9, 17]. На этой основе был проведен анализ мнений российской молодежи о перспективах и образах будущего социально-политического развития страны по ключевым индикаторам.

Перспективы развития внутренней и внешней политики глазами российской молодежи. Политическое развитие страны традиционно определяется деятельностью и эффективностью политической власти. В этой связи важнейшим индикатором является уровень доверия к политическим институтам и институтам гражданского общества.

Заметим, что в декабре 2020 года 62\% молодых граждан доверяли Президенту РФ. Противоположное мнение имели 26\% молодых респондентов. Высокий уровень поддержки действующего Президента сопровождается низким уровнем доверия к другим политическим институтам: Государственной Думе, политическим партиям, общественным организациям. Так, более $46 \%$ молодежи не поддерживают никакую политическую партию, 75\% уверены, что «большинство из нас не могут повлиять на политические процессы», а это подчеркивает закрепившуюся модель персонифицированной власти и высокую степень отчуждения.

На фоне столь высокого уровня доверия Президенту РФ наибольшее число молодых граждан затруднились выразить свое мнение в отношении действенности поправок в Конституцию РФ, которые были одобрены в ходе общероссийского голосования $(38 \%)$ (см. табл. 1). Почти четверть опрошенных молодых граждан утверждали, что поправки

1 Полевой этап исследования проходил в 14 регионах Российской Федерации. Выборка является репрезентативной. В основе ее построения лежит выборочный метод, базирующийся на экономико-географическом районировании страны, также учитывающий взаимозависимые характеристики генеральной совокупности (пол, возраст, образование, место жительства). Объем выборочной совокупности - 1563 респондентов. Для достижения цели исследования в рамках статьи авторами был отобран массив данных для последующего анализа, характеризующий объект исследования. С учетом Федерального закона от 30 декабря 2020 года №489-Ф3 «О молодежной политике в Российской Федерации» в данном исследовании российская молодежь определялась возрастными границами от 18 до 35 лет. 
в Конституцию РФ не окажут никакого влияния на развитие страны и общества (23\%). До пятой части молодых людей увидели положительное (21\%) и отрицательное влияние (18\%). В целом единого мнения по данному вопросу не зафиксировано, а разброс точек зрения и высокий процент неопределившихся, скорее, свидетельствует о слабой информированности молодежи относительно содержания большинства поправок.

Проблема устойчивости социально-политического развития остается одной из самых важных тем научного и политического дискурса. Тиражируется мнение, что молодежь легко может составить базу социального и политического протеста, выйдя при наличии поводов на улицы городов ${ }^{2}$. Однако сама молодежь, как показывают наши исследования по общероссийской выборке, демонстрирует известную степень лояльности. Более того, по мнению российской молодежи, уличные беспорядки, имевшие место на Украине и в Белорусии, не могут в ближайшее время произойти в России (52\%) (см. табл. 2). Лишь пятая часть российской молодежи полагала, что такая возможность реально существует $(22 \%)$.

Образ социально-политического развития страны в ближайшем будущем, по мнению большинства молодых россиян, тесно связан с наличием твердой руки Главнокомандующего страны, который способен навести порядок и сдержать возможные беспорядки. Так, по данным исследования, в декабре 2020 года $63 \%$ молодых граждан согласились с утверждением, что «России в целях успешного развития нужно единство власти и народа, порядок в обществе и твердая рука». Другого мнения придерживалось $37 \%$ российской молодежи, считая, что «России в целях успешного развития нужна партийная и политическая конкуренция, свобода и демократия».

В средствах массовой информации довольно часто формируется негативный образ западных стран, посредством которого

Таблица 1

Распределение ответов молодых граждан на вопрос: «Как повлияют поправки, внесенные в Конституцию России, на развитие страны и общества?» (РФ, декабрь 2020 г., \% от числа опрошенных молодых людей)

\begin{tabular}{|l|c|}
\hline \multicolumn{1}{|c|}{ Варианты ответов } & $\%$ \\
\hline Положительно & 21 \\
\hline Отрицательно & 18 \\
\hline Никак не повлияют & 23 \\
\hline Затруднились ответить & 38 \\
\hline
\end{tabular}

Таблица 2

Мнение российской молодежи о том, могут ли в России в ближайшее время произойти события, подобные тем, что произошли на Украине и в Белорусии? (РФ, декабрь 2020 г., \% от числа опрошенных молодых людей) ${ }^{4}$

\begin{tabular}{|l|c|}
\hline \multicolumn{1}{|c|}{ Варианты ответов } & $\%$ \\
\hline Могут произойти & 22 \\
\hline Не произойдут & 52 \\
\hline Затруднились ответить & 26 \\
\hline
\end{tabular}

2 Например: Бунт подростков: Навальный поднимает против Путина молодняк // Свободная пресса. URL: https://svpressa.ru/society/article/287755/.

3 Источник: Центр стратегических социальных и социально-политических исследований ИСПИ ФНИСЦ РАН.

4 Источник: Центр стратегических социальных и социально-политических исследований ИСПИ ФНИСЦ РАН. 
создается образ «внешнего врага». В отличие от старшего поколения, в большей степени привязанного к традиционным СМИ, большинство молодых людей считали, что Россия должна активно развивать отношения с остальным миром (49\%) (см. табл. 3). Четвертая часть молодых граждан говорили, что Россия должна снизить свою активность на международной арене и сосредоточиться на своих внутренних проблемах (24\%).

Учитывая, что артикулированной угрозой в публичном пространстве является вопрос о территориальной целостности России, интересно посмотреть на позицию молодежи относительно геополитических процессов. Единого мнения по этому вопросу у молодых людей не сформировано: треть молодых граждан считали, что рано или поздно вокруг России начнется процесс объединения народов (33\%) (см. табл. 4). «Россия будет су- ществовать в нынешних границах» - такой вариант ответа выбрали $29 \%$ молодых россиян. Только лишь $5 \%$ молодых респондентов сказали, что Россия обречена на дальнейший распад. Затруднились ответить $31 \%$ опрошенных молодых россиян.

Итак, перспективы реального положительного влияния поправок в Конституцию РФ на развитие страны и общества весьма туманны и неопределенны. Мнения российской молодежи разделились по данному вопросу. Однако наибольшая ее часть настроена достаточно аполитично. Образ будущего социально-политического развития страны в контексте оценки перспектив внутренней политики российской молодежью дополняется желанием видеть во главе страны руководителя с твердой рукой, который способен навести порядок и обеспечить единство власти и общества. По мнению большинства

Таблица 3

Мнение российской молодежи о том, каким образом Россия должна строить свои отношения с окружающим миром, исходя из своих национальных интересов (РФ, декабрь 2020 г., \% от числа опрошенных молодых людей)

\begin{tabular}{|l|c|}
\hline \multicolumn{1}{|c|}{ Варианты ответов } & $\%$ \\
\hline Россия должна активно развивать отношения с остальным миром & 49 \\
\hline $\begin{array}{l}\text { Россия должна снизить свою активность на международной арене и сосредото- } \\
\text { читься на своих внутренних проблемах }\end{array}$ & 24 \\
\hline $\begin{array}{l}\text { Отношения между Россией и остальным миром должны оставаться такими, какие } \\
\text { они есть сейчас }\end{array}$ & 12 \\
\hline Затруднились ответить & 15 \\
\hline
\end{tabular}

Распределение ответов молодых граждан на вопрос:

«Какое, по Вашему мнению, будущее ожидает Россию?» (РФ, декабрь 2020 г., \% от числа опрошенных молодых людей)

\begin{tabular}{|l|c|}
\hline \multicolumn{1}{|c|}{ Варианты ответов } & $\%$ \\
\hline Россия обречена на дальнейший распад & 5 \\
\hline Россия будет существовать в нынешних границах & 29 \\
\hline Рано или поздно вокруг России начнется процесс объединения народов & 33 \\
\hline Другое мнение & 2 \\
\hline Затруднились ответить & 31 \\
\hline
\end{tabular}

5 Источник: Центр стратегических социальных и социально-политических исследований ИСПИ ФНИСЦ РАН. 6 Источник: Центр стратегических социальных и социально-политических исследований ИСПИ ФНИСЦ РАН. 
молодых россиян, на международной арене, исходя из своих национальных интересов, в перспективе Россия должна активно развивать отношения с остальным миром. Однако, отвечая на вопрос о том, какое будущее ожидает Россию, российская молодежь высказывает разные точки зрения. Их мнения по данному вопросу разделились на три почти равные когорты.

Российская молодежь о гражданском обществе будущего. Надо заметить, что российская молодежь так же, как и старшие поколения, имеющиеся проблемы и перспективы завтрашнего дня практически не связывает с трансформациями политического режима. Наибольшее число молодых граждан России затруднились ответить на вопрос об обществе, в котором они бы хотели жить (48\%) (см. табл. 5). Тем не менее, $29 \%$ российской молодежи ответили, что предпочли бы капиталистическое общество. Только 17\% молодых россиян выбрали для жизни социализм. В каком-то другом обществе хотели бы жить $5 \%$ опрошенных молодых людей.

Такое распределение мнений российской молодежи об обществе, в котором они хотели бы жить, во многом обусловлено представлениями и социально-политическими установками, сформированными в процессе социализации молодых граждан. Так, в сознании молодежи сущностное ядро «капитализма» тесно связано с такими понятиями, как частная собственность (67\%), конкуренция $(63 \%)$, технический прогресс (48\%), власть узкой группы людей (40\%), корруп- ция (33\%), высокий уровень жизни (26\%), свобода (23\%), социальная незащищенность (22\%). А в основе дефиниции «социализм» лежат следующие составляющие ее характеристики: патриотизм (43\%), порядок (40\%), коллективизм (38\%), взаимопомощь (26\%), справедливость $(25 \%), \quad$ нравственность (22\%), бедность (21\%), технический прогресс $(21 \%)$.

Более того, по мнению молодежи, в основу политики развития, независимости и процветания России должны лечь такие понятия, как «мир» $(50 \%)$ и «закон» $(50 \%)$ (см. табл. 6). От пятой части до половины опрошенных молодых людей образ будущего социально-политического развития страны связывали с реализацией и наличием «прав человека» $(38 \%)$, «порядка» $(31 \%)$, «справедливости» $(29 \%)$, «свободы» $(26 \%)$, «созидания» $(23 \%)$, «демократии» $(22 \%)$ и «патриотизма» $(21 \%)$. В меньшей степени в политику развития страны в перспективе российская молодежь вкладывала такие понятия, как «державность» $(17 \%)$, «государственность» (15\%), «частная собственность» (14\%), «культура» (14\%), «Российская империя» $(13 \%)$, «равенство» $(11 \%)$, «взаимопомощь» (11\%), «конкуренция» $(10 \%)$, «нравственность» $(9 \%)$, «согласие» $(8 \%)$, «капитализм» (7\%), «духовность» $(7 \%)$, «нация» $(6 \%)$, «интернационализм» $(6 \%)$, «народовластие» (5\%) и другие.

Идеальный образ социально-политического развития гражданского общества, с котором российская молодежь ассоциирует будущее России, строится на некотором

Таблица 5

Распределение ответов российской молодежи на вопрос: «Исходя из своего жизненного опыта и представлений о социализме и капитализме, в каком обществе Вы хотели бы жить?» (РФ, декабрь 2020 г., \% от числа опрошенных молодых людей) ${ }^{7}$

\begin{tabular}{|l|c|}
\hline \multicolumn{1}{|c|}{ Варианты ответов } & $\%$ \\
\hline В капиталистическом & 29 \\
\hline В социалистическом & 17 \\
\hline В каком-то другом & 6 \\
\hline Затруднились ответить & 48 \\
\hline
\end{tabular}

7 Источник: Центр стратегических социальных и социально-политических исследований ИСПИ ФНИСЦ РАН. 
гибридном конструкте, сущность которого составляют «мир» и «закон», облеченный в оболочку из сочетания отдельных сторон социализма («порядок», «справедливость», «патриотизм») и капитализма («свобода»), а также совокупности наличия «прав человека», «созидания» и «демократии».

Перспективы социально-политического и экономического развития страны в оценках молодых граждан. Оптимистические настроения молодых россиян в отношении отдельных сфер жизнедеятельности социума в ближайшем будущем прослеживаются лишь в двух областях. Оценивая перспективное положение дел, наибольшее число молодых граждан утверждали, что в ближайшие 5 лет улучшится экономическое положение страны (40\%) и ситуация в социальной сфере (44\%) (см. табл. 7). По остальным сферам жизни общества, по мнению молодых россиян, ситуация не изменится вовсе. Среди российской молодежи доминировало мнение о том, что в ближайшем будущем останется прежним положение дел в областях культуры и искусства (61\%), развития демократии, прав и свобод граждан (61\%), борьбы с коррупцией, законности и правопорядка $(57 \%)$, духовно-нравственного состояния общества $(53 \%)$, межнациональных отношений (53\%). По мнению молодых граждан, скорее не изменится, чем изменится ситуация в отношении уровня жизни населения (41\%) и международного положения страны (40\%).

Среди российской молодежи в целом преобладает позитивное социально-психологическое состояние. На вопрос «Чувствуете ли Вы уверенность в завтрашнем дне?» $42 \%$ опрошенных молодых граждан ответили положительно (см. табл. 8). Пессимизм и страх перед будущим наблюдался у четверти молодых россиян $(25 \%)$.

Таблица 6

Распределение ответов российской молодежи на вопрос:

«По Вашему мнению, какие из перечисленных понятий должны лечь в основу политики развития, независимости и процветания России?» (РФ, декабрь 2020 г., \% от числа опрошенных молодых людей) ${ }^{8}$

\begin{tabular}{|l|l|l|c|}
\hline \multicolumn{1}{|c|}{ Варианты ответов } & $\%$ & \multicolumn{1}{|c|}{ Варианты ответов } & $\%$ \\
\hline Мир & 50 & Конкуренция & 10 \\
\hline Закон & 50 & Нравственность & 9 \\
\hline Права человека & 38 & Согласие & 8 \\
\hline Порядок & 31 & Капитализм & 7 \\
\hline Справедливость & 29 & Духовность & 7 \\
\hline Свобода & 26 & Нация & 6 \\
\hline Созидание & 23 & Интернационализм & 6 \\
\hline Демократия & 22 & Народовластие & 5 \\
\hline Патриотизм & 21 & Социализм & 3 \\
\hline Державность & 17 & Народность & 2 \\
\hline Государственность & 15 & Религиозность & 2 \\
\hline Частная собственность & 14 & СССР & 2 \\
\hline Культура & 14 & Братство & 2 \\
\hline Российская империя & 13 & Православие & 1 \\
\hline Равенство & 11 & Самодержавие & \\
\hline Взаимопомощь & 11 & & \\
\hline
\end{tabular}

8 Источник: Центр стратегических социальных и социально-политических исследований ИСПИ ФНИСЦ РАН. 
Заключение. Образы будущего социально-политического развития страны с точки зрения российской молодежи строились на основе анализа трех ключевых аспектов: оценка перспектив развития внутренней и внешней политики, формирование идеального образа российского общества и описание перспектив социально-политического и экономического развития страны по различным сферам жизнедеятельности. В целом российская молодежь, оценивая перспективы развития страны в различных областях, сохраняет довольно консервативные установки, которые не очень отличаются от взглядов старших поколений. Демонстрируя уверенность в завтрашнем дне и проявляя довольно высокий уровень социально-психологического оптимизма, молодежь рисует позитивный сценарий будущего развития, главным образом, в экономической и социальной сферах жизнедеятельности общества, что ограничивает протестный потенциал российской молодежи, который не превышает $20 \%$. Более скептично молодежь оценивает перспективы развития страны в плане укрепления демократической модели и достижения прорывов на международной арене. Однако это не сильно влияет на ее установки участвовать в социальной и гражданской активности по сравнению со старшими поколениями.

Распределение ответов российской молодежи на вопрос:

«Как, по Вашему мнению, может измениться положение дел

в различных сферах жизни российского общества в ближайшие 5 лет?» (РФ, декабрь 2020 г., \% от числа опрошенных молодых людей) ${ }^{9}$

\begin{tabular}{|l|c|c|c|}
\hline \multicolumn{1}{|c|}{ Варианты ответов } & $\begin{array}{c}\text { Станет } \\
\text { лучше }\end{array}$ & $\begin{array}{c}\text { Не } \\
\text { изменится }\end{array}$ & $\begin{array}{c}\text { Станет } \\
\text { хуже }\end{array}$ \\
\hline Экономическое положение страны & 40 & 36 & 24 \\
\hline Уровень жизни населения & 32 & 41 & 27 \\
\hline Ситуация в социальной сфере (здравоохранение, образование) & 44 & 38 & 18 \\
\hline Духовно-нравственное состояние общества & 27 & 53 & 20 \\
\hline Ситуация в сфере культуры и искусства & 28 & 61 & 11 \\
\hline Межнациональные отношения & 29 & 53 & 18 \\
\hline Международное положение страны & 36 & 40 & 24 \\
\hline Развитие демократии, прав и свобод граждан & 18 & 61 & 21 \\
\hline Борьба с коррупцией, законность и правопорядок & 21 & 57 & 22 \\
\hline
\end{tabular}

Распределение ответов молодых граждан на вопрос: «Чувствуете ли Вы уверенность в завтрашнем дне?» (РФ, декабрь 2020 г., \% от числа опрошенных молодых людей) ${ }^{10}$

\begin{tabular}{|l|c|}
\hline \multicolumn{1}{|c|}{ Варианты ответов } & $\%$ \\
\hline Да & 42 \\
\hline Нет & 25 \\
\hline Затруднились ответить & 33 \\
\hline
\end{tabular}

9 Источник: Центр стратегических социальных и социально-политических исследований ИСПИ ФНИСЦ РАН. 10 Источник: Центр стратегических социальных и социально-политических исследований ИСПИ ФНИСЦ РАН. 


\section{Литература}

1. Бочко В.С., Захарчук Е.А. Методология формирования образа будущего при разработке стратегии развития территории // Журнал экономической теории. 2019. - T. 16. - №4. - С. 688-704. - DOI: 10.31063/2073-6517/2019.16-4.7.

2. Великая Н.М. Российская молодежь в поле современной политики: между традиционализмом и оппозиционностью // Вестник РГГУ. Серия: Философия. Социология. Искусствоведение. - 2020. — №2 (21). С. 57-68.

3. Глухова А.В., Сиденко О.А., Сосунов Д. В., Щеглова Д. В. В поисках желаемого будущего - российская внутриполитическая повестка дня // Социологические исследования. - 2020. — №2. - DOI: 10.31857/ S013216250008493-5.

4. Зимин В.A. «Образ будущего» в политической культуре современной России // Успехи современной науки и образования. 2016. — №9. - Т. 2. - С. 172-175.

5. Зубок Ю.А. Традиционное и современное в социально-политических идентификациях молодежи // Власть. — 2014. — №11. С. 39-43.

6. Зубок Ю.А., Чупров В.И. Жизненные стратегии молодежи: реализация ожиданий и социальные настроения // Мониторинг общественного мнения: экономические и социальные перемены. - 2020. - №3. - С. 13-41. DOI: 10.14515/monitoring.2020.3.1602.

7. Зубок Ю.А., Чупров В.И. Социология молодежи: учебник. - М.: Норма, 2011. $336 \mathrm{c}$.

8. Ковалева А.И., Луков В.А. Социология молодежи. - М.: Социум, 1999. - 351 с.

9. Куда идешь, Россия? Экспресс-информация / В.К. Левашов, Н.М. Великая, И.С. Шушпанова и др.; отв. ред. В.К. Левашов; ФНИСЦ РАН. - М.: ФНИСЦ PAH, 2021. - 47 c. - DOI: 10.19181/ monogr.978-5-89697-344-7.2021.

10. Левашов В.К., Шушпанова И.С., Афанасьев В.А., Новоженина О. П. Социально-политические ценностные ориентации российской молодежи // Культурное пространство молодежи: смыслы и практики. Материалы Всероссийской научно-практической конференции. Под общей редакцией
Т.К. Ростовской. - М.: Издательский дом «Перспектива», 2019. - С. 167-173.

11. Луков В.А., Погорский Э.К., Тихомиров Д. А. Государственная молодежная политика: российская и мировая практика реализации в обществе инновационного потенциала новых поколений // Знание. Понимание. Умение. - 2011. - №4. - С. 231-236.

12. Образ будущего в оценках нового поколения россиян: монография / В.В. Гаврилюк, Л. Л. Мехришвили, Н. И. Скок, Х.Н. Садыкова, Ш.Ф. Фарахутдинов, В.В. Маленков, Т.В. Гаврилюк, О. Л. Сотков, И.Н. Голиков. - Тюмень: ТИУ, 2016.

13. Саморегуляция жизнедеятельности молодежи: методология и социальные практики: монография / Ю.А. Зубок, О.Н. Безрукова, Ю.Р. Вишневский и др.; науч. ред. Ю.А. Зубок. - Белгород: ООО «Эпицентр», 2021. - $500 \mathrm{c}$.

14. Стратегия прорыва и цифровая реальность России. Социально-политическое положение и демографическая ситуация в 2019 году: коллективная монография // под ред. Г.В. Осипова, С.В. Рязанцева, В.К. Левашова, Т.К. Ростовской. - М.: Перспектива, 2019. - $786 \mathrm{c.}$

15. Чупров В.И. Становление отечественной школы социологии молодежи // Россия реформирующаяся: ежегодник / отв. ред. М.К. Горшков. - М.: Новый Хронограф, 2019. - Вып. 17. - С. 103-125.

16. Шушпанова И.С. Российская молодежь о целях развития страны и национальных проектах // Государственная молодежная политика: национальные проекты 2019-2024 гг. в социальном развитии молодежи. Материалы Всероссийской научно-практической конференции. Федеральный научно-исследовательский социологический центр, Институт социальнополитических исследований. - М.: Издательский дом «Перспектива», 2020. - С. 515-527.

17. Экспресс-информация. Как живешь, Россия? 50 этап социологического мониторинга, август-сентябрь 2020 года: монография/ В.К. Левашов, Н.М. Великая, И.С. Шушпанова и др.; отв. ред. В.К. Левашов. ФНИСЦ PAH. - M.: Перспектива, 2020 - 64 c. - DOI: 10.19181/monogr.978-5-88045-463-1.2020.

18. Polak F. The Image of the Future. Amsterdam, London, New York: Elsevier Scientific Publishing Company, 1973. - 320 p. 
19. Pronovost Gilles. On constructing Typologies of Young People's Cosmopolitanism // Youth and Globalization. - 2020. - Vol. 2. №1. - P. 2-17.

\section{References}

1. Bochko V.S., ZaharchukE.A. Metodologija formirovanija obraza budushhego pri razrabotke strategii razvitija territorii [Methodology of forming the image of the future in the development of a strategy for the development of the territory] // Zhurnal jekonomicheskoj teorii [Journal of Economic Theory]. — 2019. Vol. 16. — №4. - Pp. 688-704. - DOI: 10.31063/2073-6517/2019.16-4.7.

2. Velikaja N.M. Rossijskaja molodezh' v pole sovremennoj politiki: mezhdu tradicionalizmom i oppozicionnost'ju [Russian youth in the field of modern politics: between traditionalism and Opposition] // Vestnik RGGU. Serija: Filosofija. Sociologija. Iskusstvovedenie [Bulletin of the RSUH. Series: Philosophy. Sociology. Art history]. - 2020. - №2 (21). Pp. 57-68.

3. Gluhova A. V., Sidenko O.A., Sosunov D. V., Shheglova $D$. V. V poiskah zhelaemogo budushhego - rossijskaja vnutripoliticheskaja povest$\mathrm{ka}$ dnja [In search of the desired future - the Russian domestic political agenda] // Sociologicheskie issledovanija [Sociological research]. - 2020. — №2. - DOI: 10.31857/ S013216250008493-5.

4. Zimin V.A. «Obraz budushhego» v politicheskoj kul'ture sovremennoj Rossii [«The image of the future» in the political culture of modern Russia] // Uspehi sovremennoj nauki i obrazovanija [Achievements of modern science and education]. - 2016. - №9. - Vol. 2. Pp. 172-175.

5. ZubokJu. A. Tradicionnoe i sovremennoe v social'no-politicheskih identifikacijah molodezhi [Traditional and modern in socio-political identifications of youth] // Vlast' [Power]. 2014. — №11. - Pp. 39-43.

6. Zubok Ju. A., Chuprov V.I. Zhiznennye strategii molodezhi: realizacija ozhidanij i social'nye nastroenija [Life strategies of youth: realization of expectations and social moods]// Monitoring obshhestvennogo mnenija: jekonomicheskie i social'nye peremeny [Monitoring public opinion: economic and social chang- es]. - 2020. — №3. - Pp. 13-41. - DOI: 10.14515/monitoring.2020.3.1602.

7. Zubok Ju. A., Chuprov V.I. Sociologija molodezhi: uchebnik [Sociology of Youth: textbook]. - Moscow: Norma, 2011. - 336 p.

8. Kovaleva A.I., Lukov V.A. Sociologija molodezhi [Sociology of Youth]. - Moscow: Socium, 1999. - $351 \mathrm{p}$.

9. Kuda idesh', Rossija? Jekspress-informacija [Where are you going, Russia? Express information] / V.K. Levashov, N.M. Velikaja, I.S. Shushpanova i dr.; In V.K. Levashov (eds.); FNISC RAN. - Moscow: FNISC RAN, 2021. - 47 p. - DOI: 10.19181/ monogr.978-5-89697-344-7.2021.

10. Levashov V.K., ShushpanovaI.S., Afanas'ev V. A., Novozhenina O.P. Social'nopoliticheskie cennostnye orientacii rossijskoj molodezhi [Socio-political value orientations of Russian youth] // Kul'turnoe prostranstvo molodezhi: smysly i praktiki. Materialy Vserossijskoj nauchno-prakticheskoj konferencii [The Cultural space of youth: meanings and practices. Materials of the All-Russian Scientific and Practical Conference]. In T.K. Rostovskaya (eds.). - Moscow: Izdatel'skij dom «Perspektiva», 2019. - Pp. 167-173.

11. Lukov V.A., Pogorskij Je. K., Tihomirov D. A. Gosudarstvennaja molodezhnaja politika: rossijskaja i mirovaja praktika realizacii $\mathrm{v}$ obshhestve innovacionnogo potenciala novyh pokolenij [State youth policy: Russian and world practice of implementing the innovative potential of new generations in society] // Znanie. Ponimanie. Umenie [Knowledge. Understanding. Skill]. - 2011. — №4. - Pp. 231-236.

12. Obraz budushhego $\mathrm{v}$ ocenkah novogo pokolenija rossijan: monografija [The way of the future in the estimates of the new generation of Russians: monograph] / V.V. Gavriljuk, L.L. Mehrishvili, N.I. Skok, H.N. Sadykova, Sh. F. Farahutdinov, V.V. Malenkov, T.V. Gavriljuk, O.L. Sotkov, I.N. Golikov. - Tjumen': TIU, 2016.

13. Samoreguljacija zhiznedejatel'nosti molodezhi: metodologija i social'nye praktiki: monografija [Self-regulation of the life of young people: methodology and social practices: monograph] / Ju. A. Zubok, O.N. Bezrukova, Ju. R. Vishnevskij i dr.; In Ju. A. Zubok (eds.). Belgorod: OOO «Jepicentr», 2021. - 500 p.

14. Strategija proryva i cifrovaja real'nost' Rossii. Social'no-politicheskoe polozhenie i de- 
mograficheskaja situacija v 2019 godu: kollektivnaja monografija [The Breakthrough Strategy and the digital reality of Russia. Socio-political situation and demographic situation in 2019: collective monograph] // In G. V. Osipov, S. V. Rjazancev, V.K. Levashov, T. K. Rostovskaya (eds.). - Moscow: Perspektiva, 2019. - 786 p.

15. Chuprov V.I. Stanovlenie otechestvennoj shkoly sociologii molodezhi [Formation of the national school of youth sociology] // Rossija reformirujushhajasja: ezhegodnik [Russia being Reformed: Yearbook] / In M. K. Gorshkov (eds.). - Moscow: Novyj Hronograf, 2019. Issue 17. - Pp. 103-125.

16. Shushpanova I.S. Rossijskaja molodezh' o celjah razvitija strany i nacional'nyh proektah [Russian youth on the goals of the country's development and national projects] // Gosudarstvennaja molodezhnaja politika: nacional'nye proekty 2019-2024 gg. V social'nom razvitii molodezhi. Materialy Vserossijskoj nauchnoprakticheskoj konferencii. Federal'nyj nauchnoissledovatel'skij sociologicheskij centr, Institut social'no-politicheskih issledovanij [State youth policy: national projects 2019-2024 in the social development of young people. Materials of the All-Russian Scientific and Practical Conference. Federal Research Sociological Center, Institute of Socio-Political Studies]. - Moscow: Izdatel'skij dom «Perspektiva», 2020. Pp. 515-527.

17. Jekspress-informacija. Kak zhivesh', Rossija? 50 jetap sociologicheskogo monitoringa, avgust-sentjabr' 2020 goda: monografija [Express information. How do you live, Russia? 50 stage of sociological monitoring, August-September 2020: monograph] / V.K. Levashov, N.M. Velikaja, I.S. Shushpanova i dr.; In V.K. Levashov (eds.). FNISC RAN. Moscow: Perspektiva, 2020. - 64 p. - DOI: 10.19181/monogr.978-5-88045-463-1.2020.

18. Polak F. The Image of the Future. Amsterdam, London, New York: Elsevier Scientific Publishing Company, 1973. - 320 p.

19. Pronovost Gilles. On constructing Typologies of Young People's Cosmopolitanism // Youth and Globalization. - 2020. - Vol. 2. №1. - P. 2-17.

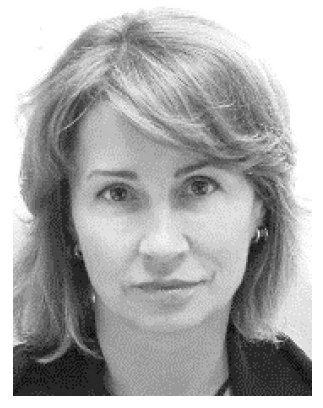

Великая Наталия Михайловна - доктор политических наук, заместитель директора по научной работе, главный научный сотрудник Института социально-политических исследований Федерального научно-исследовательского социологического центра Российской академии наук; декан социологического факультета Российского государственного гуманитарного университета (РГГУ).

Velikaya Natalia Mikhailovna - Doctor of Political Sciences, Deputy Director of Science and Research, Main Researcher, Institute of Socio-Political Research of the Federal Center of Theoretical and Applied Sociology of the Russian Academy of Sciences; Dean of the Sociology Faculty of Russian State University for the Humanities.

119333 , г. Москва, ул. Фотиевой, 6, стр. 1 6 Fotievoi st., bld. 1, 119333, Moscow, Russia,

E-mail: natalivelikaya@gmail.com

125993, г. Москва, Миусская пл., 6 6 Miusskaya sq., 125993, Moscow, Russia,

E-mail: natalivelikaya@gmail.com) 


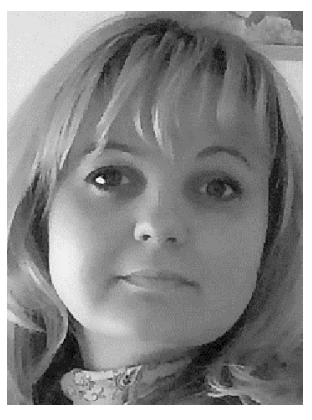

Шушпанова Ирина Сергеевна - кандидат социологических наук, доцент, ученый секретарь, ведущий научный сотрудник Института социально-политических исследований Федерального научно-исследовательского социологического центра Российской академии наук.

Shushpanova Irina Sergeevna - Candidate of Sociological Sciences, Associate Professor, Academic Secretary of the branch, Leading Researcher, Institute of Socio-Political Research of the Federal Center of Theoretical and Applied Sociology of the Russian Academy of Sciences.

119333, г. Москва, ул. Фотиевой, 6, стр. 1

6 Fotievoi st., bld. 1, 119333, Moscow, Russia,

E-mail: i.s.shushpanova@mail.ru 